Brit. J. industr. Med., 1959, 16, 43.

\title{
THE DUST CONTENT OF THE LUNGS OF COAL WORKERS FROM CUMBERLAND
}

\author{
BY \\ J. S. FAULDS, E. J. KING, and G. NAGELSCHMIDT \\ From Cumberland Pathological Laboratory, Carlisl, the Postgraduate Medical School, London, \\ and the Safety in Minss Research Establishment, Sheffield
}

(RECEIVED FOR PUBLICATION JANUARY 28, 1958)

The prevalence of pneumoconiosis varies from one coalfield to another. The present investigation arose from the observation that coal-miners' lungs from west Cumberland appeared much less black and had less coal in them than lungs from South Wales coal-miners.

Dust analyses were carried out on 33 lungs of coal workers from Cumberland which had been examined histologically and graded according to the classification of Belt and King (1945). No case of massive fibrosis (grade 4) occurred and this condition seems to be rare or absent in Cumberland. Compared with South Wales coal-miners' lungs, each histological grade of simple pneumoconiosis was on an average associated with less coal dust and more rock dust in Cumberland, and silicosis due to rock work in coal-mines appeared to be relatively more frequent.

According to certification statistics and direct surveys the prevalence of pneumoconiosis varies from one coalfield to another, and until about 1950 the bulk of the disease in Great Britain was found in the anthracite and steam coal areas of South Wales. A number of lungs from coal workers from these regions have been analysed for their dust content with the general conclusion that the kind of work (rock worker, collier, trimmer) was reflected in the lung dust composition and that increased severity of the disease was associated with increasing amounts of dust (King and Nagelschmidt, 1945; King, Maguire, and Nagelschmidt, 1956).

The present investigation arose from the repeated observations of all three of us on coal-miners' lungs received from west Cumberland that they appeared much less black and on analysis had less coal in them than lungs from South Wales; and the observation of one of us (J.S.F.) that the type of " black lung" characteristic of the advanced stages of pneumoconiosis seen in South Wales (Fig. 4) appeared to be absent in the lungs of coal workers seen at necropsy in west Cumberland. There is believed to be as much dust in the west Cumberland mines as elsewhere, and there appears to be no reason why the coal dust should be inhaled less readily, or eliminated more rapidly, than Welsh coal dust.

Progressive massive fibrosis (P.M.F.) is characterized by a confluent fibrosis, pigmented with carbon, whose origin is considered to be due to chronic infection, frequently, but not invariably, tubercular, superimposed upon a background of simple pneumoconiosis (cf. Cochrane and Miall, 1956). The absence of P.M.F. in Cumberland in contrast with Wales was first observed from 1940 to 1948 when the active interest in coal-miners' pneumoconiosis was developing throughout the various coalfields. At the Cumberland Infirmary, Carlisle, lungs were obtained from coal-miners, $(a)$ whose death resulted from accident or natural causes and where no question of compensation for pulmonary disease arose, but whose working lives had been spent as miners, and (b) from men to whose death pneumoconiosis was thought to have contributed and consequently postmortem examinations were ordered by the coroner. The lungs of all these coal-miners were examined during the last 10 years and advanced stages of P.M.F. would have been detected had they existed. There is as much pulmonary tuberculosis in west Cumberland as in Wales and the reports of the County Medical Officer of Health and of the Registrar General reveal that the incidence in certain villages is twice that of England and Wales (Faulds, 1957). The area was scheduled as a depressed area in the early twenties and there was mass unemployment after the general strike. The standard of housing was low and the population has a strong Irish element prone to tuberculous infection (Faulds, 1957).

For these reasons it was considered desirable to analyse a number of lungs to assess the amount and composition of the dust present, and between 1948 


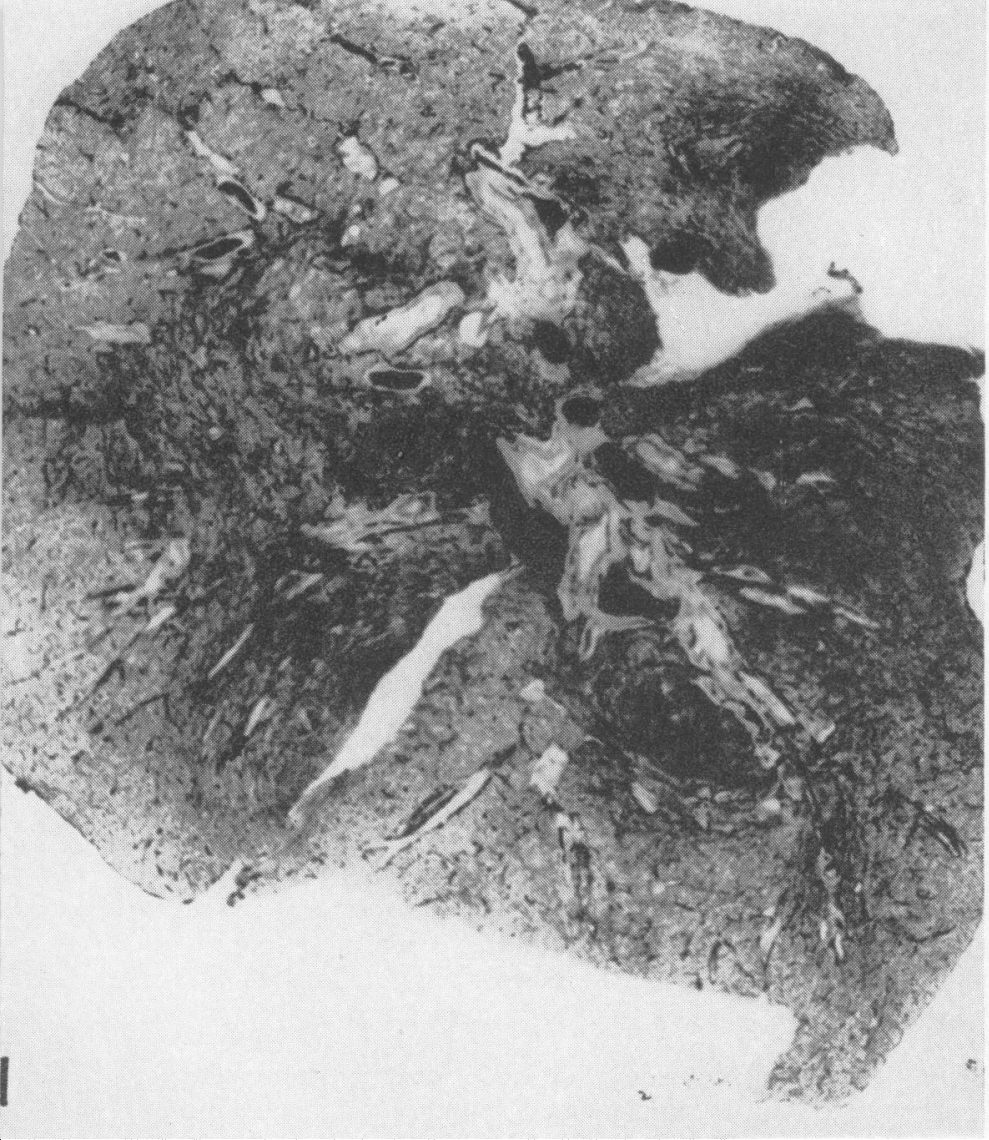

Fig. 1.-Cumberland coal-miner's lung: 40 years' exposure; showing only a little coal dust; slight reticulation, Grade 1; No. 3627.

Fig, 2-Cumberland coal-miner's lung: reticulation and focal emphysema, Grade No. 2; 5648.

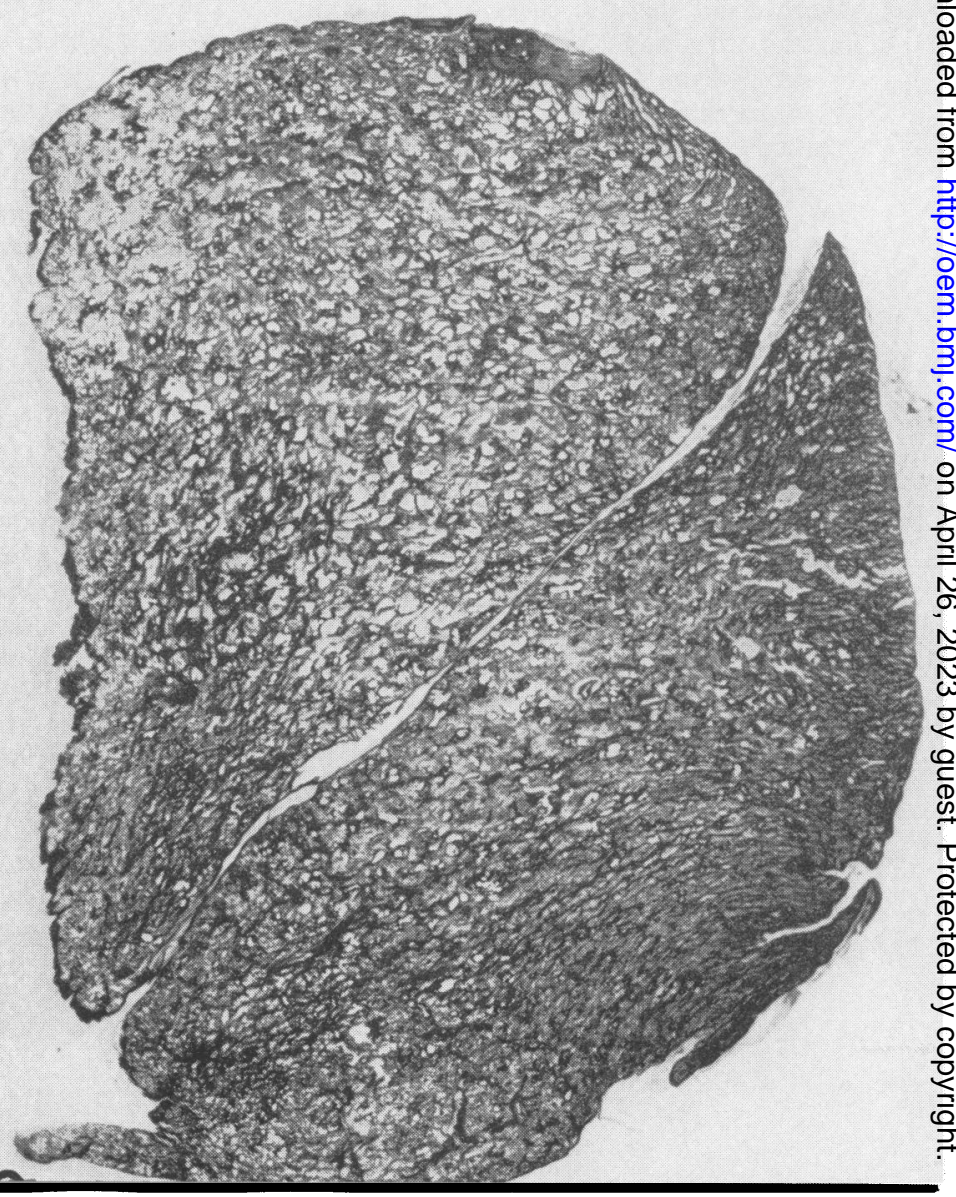




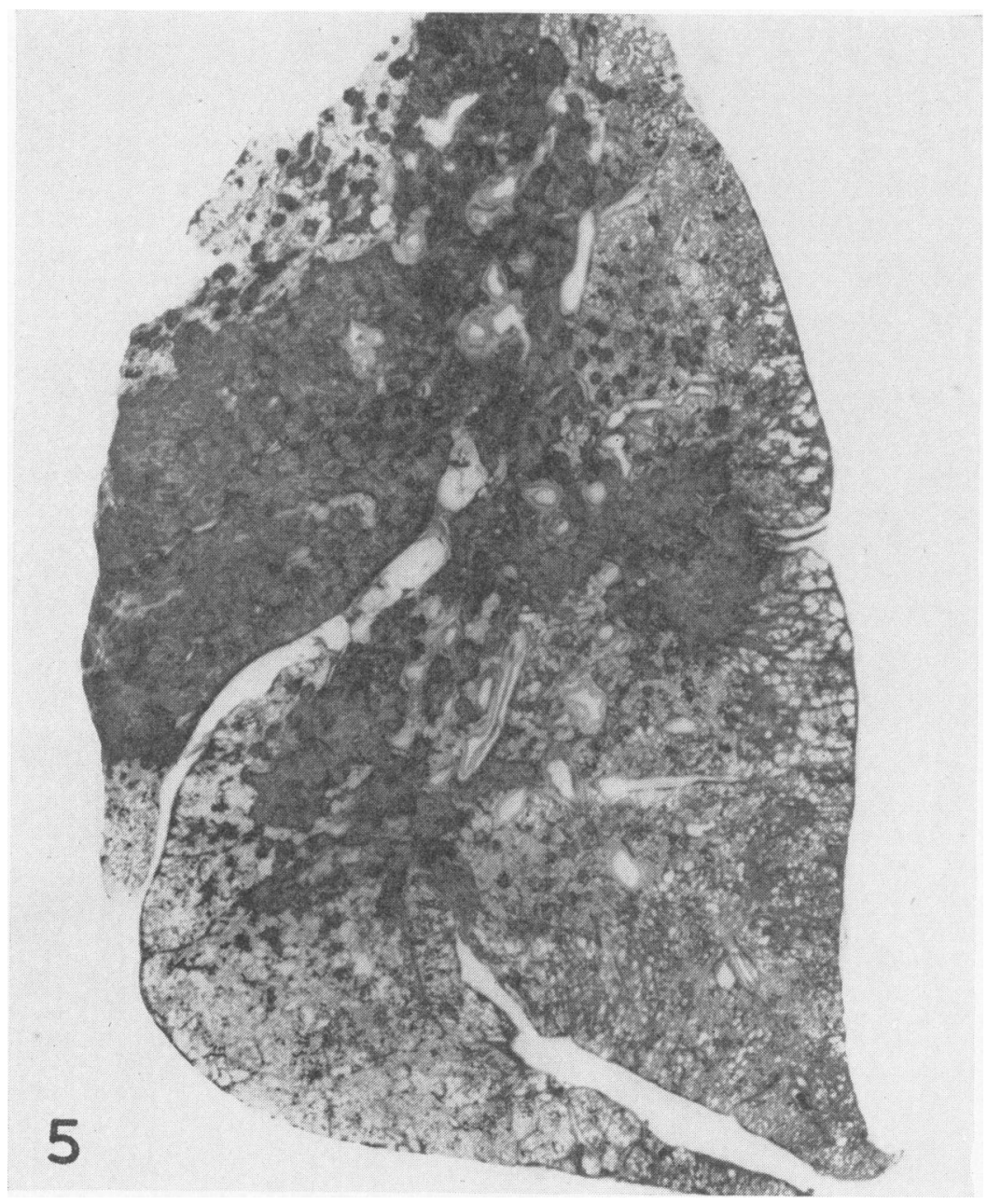

Fig. 5.-Cumberland lung: rock dust and some coal dust; silicotic nodulation; No. 5489.

and 1955 all lungs from men who died in the pits as a result of coronary disease or accident, or who died in hospital, and whose industrial history was known, were retained. Since, in Cumberland, there have been few claims in the past for compensation on account of pneumoconiosis, there were very few radiological examinations made shortly before death, and there was little radiographic evidence of pneumoconiosis for the period covered. Before the National Coal Board took over the mines, accurate records of the types of work undertaken by the workmen during their period of service with the individual pits were not available, and it was therefore difficult to obtain accurate industrial histories in many cases. Also, with the shifting of the popu- lation from one pit to another, owing to the exhaustion of the seams, we had frequently to rely on the observations of workmates.

Reasonably accurate histories of work were available in only 33 cases. These form the subject of the present paper. They were classified, according to type of work, into three broad classes, those exposed mainly to rock dust, to mixed dust, and to coal dust. These classes were used because it was often found difficult to assign the men to distinct occupations such as collier, haulier, or rock worker. It may be that in the Cumberland coalfield there is a greater tendency for men to move from one type of work to another in the pit than there is in South Wales. 


\section{Experimental}

The histological assessments were carried out in sections of blocks taken from several parts of the lung, assisted by large sections which were prepared for us by Professor J. Gough, and the pathological grading was in accordance with that originally described by Belt and King (1945) as modified by Gough (see King et al., 1956), namely, (1) slight reticulation (Fig. 1), (2) reticulation (Fig. 2), (3) mixed nodulation (Fig. 3), (4) confluent fibrosis (Fig. 4), and (5) silicotic nodulation (Fig. 5). The lung dust was isolated and analysed as described previously. Coal was determined from a small sample of dried lung tissue, usually $\frac{1}{2}$ or $1 \mathrm{~g}$., and the mineral (non-coal) residue was isolated from a larger sample, usually $50 \mathrm{~g}$. Total silica was determined chemically and the quartz content by a quantitative $x$-ray diffraction technique (Gordon and Harris, 1956). Apart from quartz, mica was the main constituent of the mineral fraction, and kaolin was found in minor amounts in many but not all of the residues. The total lung weight was available in 27 of the 33 cases.

The lungs examined are classified in Table 1 according to dust exposure and pathological grading. Half the cases showed grade 2 , but grade 4 (confluent fibrosis) was absent. This is in strong contrast to the distribution seen in necropsy material in Cardiff (Gough, 1954) where between 1946 and 1948 only about one-fifth of all lungs showed grade 2 and half the material was of grade 4 , i.e., confluent fibrosis. Although statistically neither
TABLE 1

NUMBER OF LUNGS IN DIFFERENT PATHOLOGICAL GRADES AND DUST EXPOSURE CLASSES

\begin{tabular}{|c|c|c|c|c|c|c|c|}
\hline \multirow{2}{*}{$\begin{array}{c}\text { Dust Exposure } \\
\text { Class }\end{array}$} & \multicolumn{5}{|c|}{ Pathological Grade } & \multirow{2}{*}{$\begin{array}{l}\text { No. of } \\
\text { Men }\end{array}$} & \multirow{2}{*}{$\begin{array}{l}\text { Mean } \\
\text { Pathological } \\
\text { Grade }\end{array}$} \\
\hline & 1 & 2 & 3 & 4 & 5 & & \\
\hline $\begin{array}{l}\text { Mainly rock dust } \\
\text { Mainly mixed dust } \\
\text { Mainly coal dust }\end{array}$ & $\begin{array}{l}\overline{2} \\
4\end{array}$ & $\begin{array}{r}\overline{2} \\
14\end{array}$ & $\overline{3}$ & E & $\begin{array}{r}2 \\
4 \\
-\end{array}$ & $\begin{array}{r}2 \\
11 \\
20\end{array}$ & $\begin{array}{l}5 \\
3 \cdot 2 \\
1 \cdot 9\end{array}$ \\
\hline Totals & 6 & 16 & 5 & - & 6 & 33 & \\
\hline
\end{tabular}

source is a satisfactory one for assessing the relative prevalence of the various grades of disease the difference between the two regions is nevertheless very striking.

\section{Results}

The data are given fully in Table 2, where for each of the three dust exposure classes the lungs are given in increasing grades of pathology and, within each grade, in increasing amounts of total dust expressed as percentage of the dried lung.

Grade 1 lungs, i.e., slight reticulation, showed no more discoloration than those of a city dweller, and histologically there were minute dust foci surrounded by microscopic emphysema. These foci resembled spiders' webs, with a central zone composed of

TABLE 2

DUST CONTENT OF LUNGS OF COAL WORKERS FROM CUMBERLAND

\begin{tabular}{|c|c|c|c|c|c|c|c|c|c|c|c|c|c|}
\hline \multirow{2}{*}{$\begin{array}{c}\text { Dust } \\
\text { Exposure } \\
\text { Classes }\end{array}$} & \multirow{2}{*}{$\begin{array}{l}\text { Necropsy } \\
\text { Number }\end{array}$} & \multirow{2}{*}{ Age } & \multirow{2}{*}{$\underset{\text { (years) }}{\text { Exposure }}$} & \multirow{2}{*}{$\begin{array}{l}\text { Patho- } \\
\text { logical } \\
\text { Grade }\end{array}$} & \multicolumn{5}{|c|}{ Percentage Dried Lung } & \multirow{2}{*}{$\begin{array}{l}\text { Weight of } \\
\text { Dried } \\
\text { Lung (g.) }\end{array}$} & \multirow{2}{*}{$\begin{array}{c}\text { Total } \\
\text { Estimated } \\
\text { Dust in } \\
\text { Both } \\
\text { Lungs (g.) }\end{array}$} & \multirow{2}{*}{$\begin{array}{l}\text { Ratio: } \\
\frac{\text { Coal }}{\text { Sil. Min }}\end{array}$} & \multirow{2}{*}{$\begin{array}{l}\text { Quartz as } \\
\% \text { of } \\
\text { Total } \\
\text { Lung } \\
\text { Dust }\end{array}$} \\
\hline & & & & & $\begin{array}{l}\text { Total } \\
\text { Dust }\end{array}$ & Coal & $\begin{array}{l}\text { Sil. } \\
\text { Min.* }\end{array}$ & Quartz & $\mathrm{SiO}_{2}$ & & & & \\
\hline I & $\begin{array}{l}6001 \\
5920\end{array}$ & $\begin{array}{l}73 \\
75\end{array}$ & $\begin{array}{l}52 \\
40\end{array}$ & $\begin{array}{l}5 \\
5\end{array}$ & $\begin{array}{r}7 \cdot 28 \\
15 \cdot 05\end{array}$ & $\begin{array}{l}1.05 \\
1.62\end{array}$ & $\begin{array}{r}6 \cdot 23 \\
13 \cdot 43\end{array}$ & $\begin{array}{l}1.0 \\
2.42\end{array}$ & $\begin{array}{l}3 \cdot 6 \\
7 \cdot 3\end{array}$ & $\begin{array}{l}130 \\
188\end{array}$ & $\begin{array}{l}19 \\
57\end{array}$ & $\begin{array}{l}0 \cdot 17 \\
0 \cdot 12\end{array}$ & $\begin{array}{l}14 \\
16\end{array}$ \\
\hline Mixed dust $_{\text {II }}$ & $\begin{array}{l}5983 \\
5496 \\
6161 \\
4214 \\
4629 \\
4473 \\
4409 \\
6169 \\
5489 \\
4274 \\
5980\end{array}$ & $\begin{array}{l}51 \\
74 \\
59 \\
47 \\
58 \\
40 \\
68 \\
57 \\
45 \\
61 \\
56\end{array}$ & $\begin{array}{l}20 \\
30 \\
45 \\
32 \\
40 \\
23 \\
31 \\
30 \\
27 \\
24 \\
32\end{array}$ & $\begin{array}{l}1 \\
1 \\
2 \\
2 \\
3 \\
3 \\
3 \\
5 \\
5 \\
5 \\
5\end{array}$ & $\begin{array}{c}0.81 \\
1.92 \\
3.20 \\
13.5 \\
2.44 \\
4.01 \\
7.87 \\
4.97 \\
5.23 \\
5.30 \\
6.61\end{array}$ & $\begin{array}{l}0.71 \\
1.00 \\
1.78 \\
5.8 \\
1.34 \\
1.1 \\
4.44 \\
3.08 \\
0.42 \\
0.84 \\
1.06\end{array}$ & $\begin{array}{l}0 \cdot 10 \\
0.92 \\
1 \cdot 42 \\
7 \cdot 7 \\
1 \cdot 10 \\
2.91 \\
3.43 \\
1 \cdot 89 \\
4 \cdot 81 \\
4 \cdot 46 \\
5 \cdot 55\end{array}$ & $\begin{array}{l}0.01 \\
0.1 \\
0.23 \\
0.85 \\
0.28 \\
0.44 \\
0.51 \\
0.98 \\
0.96 \\
1.5 \\
1.11\end{array}$ & $\begin{array}{l}0.05 \\
0.40 \\
0.79 \\
4.2 \\
0.69 \\
1.53 \\
1.81 \\
1.3 \\
2.64 \\
3.0 \\
3.3\end{array}$ & $\begin{array}{r}170 \\
119 \\
178 \\
170 \\
86 \\
= \\
\overline{-} \\
\overline{200} \\
\overline{97}\end{array}$ & $\begin{array}{c}2.75 \\
4.6 \\
11 \cdot 4 \\
46 \\
4 \cdot 2 \\
-_{-\dagger}^{+} \\
\bar{z}^{\dagger}+ \\
\frac{21}{12 \cdot 8}\end{array}$ & $\begin{array}{l}7 \cdot 1 \\
1 \cdot 1 \\
1 \cdot 2 \\
0 \cdot 75 \\
1 \cdot 2 \\
0 \cdot 38 \\
1 \cdot 3 \\
1 \cdot 6 \\
0 \cdot 1 \\
0 \cdot 2 \\
0 \cdot 19\end{array}$ & $\begin{array}{r}2 \\
5 \\
7 \\
6 \\
11 \\
11 \\
6 \\
20 \\
18 \\
20 \\
17\end{array}$ \\
\hline Coal dust & $\begin{array}{l}4829 \\
3627 \\
5987 \\
6181 \\
5412 \\
5053 \\
5695 \\
5014 \\
5088 \\
6178 \\
5648 \\
6065 \\
6094 \\
4115 \\
5981 \\
5885 \\
4428 \\
4148 \\
5761 \\
4865\end{array}$ & $\begin{array}{l}46 \\
67 \\
75 \\
48 \\
47 \\
45 \\
62 \\
35 \\
73 \\
67 \\
71 \\
54 \\
57 \\
70 \\
55 \\
50 \\
59 \\
62 \\
65 \\
42\end{array}$ & $\begin{array}{l}31 \\
40 \\
40 \\
33 \\
30 \\
41 \\
21 \\
48 \\
- \\
41 \\
50 \\
40 \\
35 \\
33 \\
49 \\
27\end{array}$ & $\begin{array}{l}1 \\
1 \\
1 \\
1 \\
2 \\
2 \\
2 \\
2 \\
2 \\
2 \\
2 \\
2 \\
2 \\
2 \\
2 \\
2 \\
2 \\
2 \\
3 \\
3\end{array}$ & $\begin{array}{l}0 \cdot 7 \\
2 \cdot 67 \\
3 \cdot 74 \\
4 \cdot 01 \\
0.82 \\
1 \cdot 22 \\
1 \cdot 50 \\
1 \cdot 69 \\
2 \cdot 28 \\
2 \cdot 86 \\
3.07 \\
3 \cdot 24 \\
3 \cdot 37 \\
3.5 \\
3.78 \\
5.60 \\
7 \cdot 16 \\
9 \cdot 64 \\
7.68 \\
9.4\end{array}$ & $\begin{array}{l}0.44 \\
1.26 \\
3.10 \\
2.70 \\
0.52 \\
0.49 \\
0.64 \\
0.77 \\
0.94 \\
1 \cdot 37 \\
1 \cdot 14 \\
2.68 \\
1.35 \\
1.63 \\
2.64 \\
3.38 \\
3.0 \\
7.98 \\
4.31 \\
7.56\end{array}$ & $\begin{array}{l}0.25 \\
1.41 \\
0.64 \\
1.31 \\
0 \cdot 30 \\
0.73 \\
0.86 \\
0.92 \\
1.34 \\
1.49 \\
1.93 \\
0.56 \\
2.02 \\
1.87 \\
1.14 \\
2.22 \\
4 \cdot 16 \\
1.66 \\
3.37 \\
1.84\end{array}$ & $\begin{array}{l}0.02 \\
0 \cdot 16 \\
0 \cdot 07 \\
0 \cdot 12 \\
0 \cdot 04 \\
0 \cdot 13 \\
0 \cdot 10 \\
0 \cdot 07 \\
0 \cdot 15 \\
0 \cdot 16 \\
0 \cdot 29 \\
0.09 \\
0 \cdot 24 \\
0.21 \\
0 \cdot 16 \\
0.22 \\
0.25 \\
0.46 \\
0.54 \\
0.17\end{array}$ & $\begin{array}{l}0.14 \\
0.77 \\
0.35 \\
0.60 \\
0.16 \\
0.42 \\
0.47 \\
0.50 \\
0.73 \\
0.71 \\
1.04 \\
0.32 \\
1.04 \\
1.12 \\
0.60 \\
1.18 \\
1.45 \\
0.08 \\
1.84 \\
1.10\end{array}$ & $\begin{array}{r}103 \\
\frac{62}{62} \\
119 \\
107 \\
158 \\
55 \\
134 \\
88 \\
106 \\
150 \\
201 \\
160 \\
132 \\
92 \\
128 \\
73 \\
102 \\
98\end{array}$ & $\begin{array}{r}1.4 \\
4.6 \\
9.5 \\
1.8 \\
3.8 \\
1.7 \\
4.6 \\
4.0 \\
6.0 \\
9.0 \\
13.0 \\
11.0 \\
9.2 \\
10.7 \\
10.3 \\
18.3 \\
14.0 \\
16.0 \\
18.6\end{array}$ & $\begin{array}{l}1 \cdot 8 \\
0.9 \\
4.9 \\
2.06 \\
1 \cdot 75 \\
0.67 \\
1 \cdot 74 \\
0 \cdot 84 \\
0.70 \\
0.9 \\
0.6 \\
4 \cdot 8 \\
0.7 \\
0.87 \\
2.3 \\
1 \cdot 5 \\
0.72 \\
4 \cdot 8 \\
1 \cdot 3 \\
4 \cdot 1\end{array}$ & $\begin{array}{r}3 \\
6 \\
2 \\
3 \\
5 \\
11 \\
7 \\
4 \\
6 \\
6 \\
9 \\
3 \\
7 \\
6 \\
4 \\
4 \\
3 \\
5 \\
7 \\
2\end{array}$ \\
\hline
\end{tabular}

* Siliceous minerals, i.e., the sum of kaolin, mica, and quartz. 
dust-laden macrophages in varying degrees of disintegration, and thickened alveolar walls radiating out from the focus. The dust foci, usually associated with peribronchial and perivascular lymphatics, were scattered generally throughout the lung, but were more numerous in the upper lobes and upper part of the lower lobes. Grade 2 resembled grade 1 , but with a greater concentration of the dust foci and more emphysema. The emphysematous areas were generally larger and more prominent.

The five lungs of the present series belonging to grade 3 fell into two different classes and the histological picture reflected the different nature of dust to which they had been exposed. Necropsies Nos. 4865 and 5761 (see Table 2) were of men who had worked mainly in coal dust. The fibrosis was more diffuse, less dense and hyaline, and there was little nodulation. The coal dust was collected into small areas with distinct emphysematous bullae easily recognized by the naked eye. In these two cases there was no histological evidence of tubercle. In the other three, Nos. 4409, 4473, and 4629, all of whom had worked in mixed dust, the reticulation had microscopic nodulation. These nodules, $0.5 \mathrm{~mm}$. to $3.0 \mathrm{~mm}$. in diameter, were composed of hyaline fibrous tissue and had no condensed edge, but tended to coalesce into larger masses. The amount of carbon pigmentation was smaller microscopically than in the former two cases and quartz crystals could be demonstrated more easily. In two of these three cases there was histological evidence of a terminal tuberculous infection. The lung dust analyses confirmed the histological findings except for necropsy No. 5761 which had a higher quartz content than would have been expected.

There were no cases of massive fibrosis, and the cases classified as grade 5 showed the characteristic picture of nodular silicosis with collagenous nodules relatively free from coal dust.

The analytical data are set out in the same way as previously (King et al., 1956), but quartz as a percentage of total lung dust has been added in view of the apparently more important role it occupies as a factor in causing lung disease in Cumberland coal workers.

Mean results for the exposure classes are given in Table 3A. The two rock workers, who had both been master drifters, showed significantly more rock dust and more quartz when expressed as a percentage of dried lung than either of the other two groups, and the same criteria distinguished the mixed dust from the pure coal dust group. This confirms that the grouping was reasonable; it had been based on the environmental histories before the analytical work was started.

The differences for the pathological grades are shown in Table 4A, and results, expressed in grams of the different dust constituents in both lungs, are compared with data from South Wales (King et al., 1956) in Fig. 6.

With the increase of the pathological grade, a corresponding increase in the amount of dust was observed; as Table 4B shows, these increases were not significant when comparing each grade with the next one, but the differences between grades 3 and 1 were significant at the $2 \%$ level for total dust, at

TABLE 3A

DUST CONTENT FOR DIFFERENT DUST EXPOSURE CLASSES

\begin{tabular}{|c|c|c|c|c|c|c|c|}
\hline \multirow{2}{*}{$\begin{array}{c}\text { Type of } \\
\text { Dust }\end{array}$} & \multirow{2}{*}{$\underset{\text { Men }}{\text { Number of }}$} & \multirow{2}{*}{$\begin{array}{c}\text { Mean Dust } \\
\text { Exposure } \\
\text { (years) }\end{array}$} & \multicolumn{4}{|c|}{ Percentage Dried Lung } & \multirow{2}{*}{$\begin{array}{l}\text { Total Estimated } \\
\text { Dust in } \\
\text { Both Lungs (g.) }\end{array}$} \\
\hline & & & $\begin{array}{l}\text { Total } \\
\text { Dust }\end{array}$ & Coal & $\begin{array}{l}\text { Sil. } \\
\text { Min. }\end{array}$ & Quartz & \\
\hline $\begin{array}{l}\text { Rock } \\
\text { Mixed } \\
\text { Coal }\end{array}$ & $\begin{array}{r}2 \\
11 \\
20\end{array}$ & $\begin{array}{l}46 \\
30 \\
37\end{array}$ & $\begin{array}{c}11 \cdot 2 \\
(3 \cdot 9) \\
5 \cdot 1 \\
(1 \cdot 0) \\
3 \cdot 9 \\
(0 \cdot 7)\end{array}$ & $\begin{array}{c}1 \cdot 3 \\
(0 \cdot 3) \\
2 \cdot 0 \\
(0 \cdot 5) \\
2 \cdot 4 \\
(0 \cdot 6)\end{array}$ & $\begin{array}{c}9 \cdot 8 \\
(3 \cdot 6) \\
3 \cdot 1 \\
(0 \cdot 7) \\
1 \cdot 5 \\
(0 \cdot 2)\end{array}$ & $\begin{array}{c}1.71 \\
(0.71) \\
0.63 \\
(0.15) \\
0.18 \\
(0.05)\end{array}$ & $\begin{array}{l}38 \\
(19) \\
14 \cdot 7 * \\
(5 \cdot 8) \\
7 \cdot 8 \dagger \\
(1.6)\end{array}$ \\
\hline
\end{tabular}

Figures in brackets are standard errors of means.

*Based on seven lungs.

†Based on 18 lungs.

TABLE 3B

SIGNIFICANCE LEVELS OF DIFFERENCES OF MEAN VALUES IN TABLE 3A

\begin{tabular}{|c|c|c|c|c|c|}
\hline \multirow{3}{*}{ Differences of Occupational Dust Exposures } & \multicolumn{5}{|c|}{ Significance Level ( $\%$ ) for: } \\
\hline & \multicolumn{4}{|c|}{ Percentage Dried Lung } & \multirow{2}{*}{$\begin{array}{l}\text { Total Estimated } \\
\text { Dust in } \\
\text { Both Lungs (g.) }\end{array}$} \\
\hline & $\begin{array}{l}\text { Total } \\
\text { Dust }\end{array}$ & Coal & $\begin{array}{l}\text { Sil. } \\
\text { Min. }\end{array}$ & Quartz & \\
\hline $\begin{array}{l}\text { Rock dust minus mixed dust } \\
\text { Rock dust minus coal dust } \\
\text { Mixed dust minus coal dust }\end{array}$ & $\begin{array}{r}10 \\
1 \\
\text { NS }\end{array}$ & $\begin{array}{l}\text { NS } \\
\text { NS } \\
\text { NS }\end{array}$ & $\begin{array}{l}1 \\
0 \cdot 1 \\
1\end{array}$ & $\begin{array}{l}5 \\
0 \cdot 1 \\
1\end{array}$ & $\begin{array}{l}\text { NS } \\
0 \cdot 1 \\
\text { NS }\end{array}$ \\
\hline
\end{tabular}

NS $=$ not significant. 
TABLE 4A

DUST CONTENT OF LUNGS FOR VARIOUS PATHOLOGICAL GRADES

\begin{tabular}{|c|c|c|c|c|c|c|c|}
\hline \multirow{2}{*}{$\begin{array}{l}\text { Pathological } \\
\text { Grade }\end{array}$} & \multirow{2}{*}{$\underset{\text { Men }}{\text { Number of }}$} & \multirow{2}{*}{$\begin{array}{c}\text { Mean Dust } \\
\text { Exposure } \\
\text { (years) }\end{array}$} & \multicolumn{4}{|c|}{ Percentage Dried Lung } & \multirow{2}{*}{$\begin{array}{l}\text { Total Estimated } \\
\text { Dust in } \\
\text { Both Lungs (g.) }\end{array}$} \\
\hline & & & $\begin{array}{l}\text { Total } \\
\text { Dust }\end{array}$ & Coal & $\begin{array}{l}\text { Sil. } \\
\text { Min. }\end{array}$ & Quartz & \\
\hline 1 & 6 & 32 & $\begin{array}{l}2 \cdot 31 \\
(0 \cdot 6)\end{array}$ & $\begin{array}{l}1 \cdot 54 \\
(0 \cdot 4)\end{array}$ & $\begin{array}{c}0 \cdot 77 \\
(0 \cdot 2)\end{array}$ & $\begin{array}{c}0.08 \\
(0.02)\end{array}$ & $4 \cdot 6^{*}$ \\
\hline 2 & 16 & 36 & $\begin{array}{r}4 \cdot 15 \\
(0.8)\end{array}$ & $\begin{array}{l}2 \cdot 26 \\
(0 \cdot 5)\end{array}$ & $\begin{array}{l}1.89 \\
(0.4)\end{array}$ & $\begin{array}{l}0.23 \\
(0.05)\end{array}$ & $10 \cdot 9+$ \\
\hline 3 & 5 & 30 & $6 \cdot 28$ & $\begin{array}{l}3.75 \\
(1.2)\end{array}$ & $\begin{array}{r}2.53 \\
(0.5)\end{array}$ & $\begin{array}{l}0.39 \\
(0.07)\end{array}$ & $12 \cdot 9 \ddagger$ \\
\hline 5 & 6 & 32 & $\begin{array}{l}7.41 \\
(1 \cdot 6)\end{array}$ & $\begin{array}{l}1.34 \\
(0.4)\end{array}$ & $\begin{array}{l}6.06 \\
(1.6)\end{array}$ & $\begin{array}{c}1 \cdot 33 \\
(0 \cdot 23)\end{array}$ & $27 \cdot 4 \S$ \\
\hline
\end{tabular}

Figures in brackets are standard errors of means.

* Based on five lungs.

$\ddagger$ Based on three lungs.

TABLE 4B

SIGNIFICANCE LEVELS OF DIFFERENCES OF MEAN VALUES GIVEN IN TABLE 4A

\begin{tabular}{|c|c|c|c|c|c|}
\hline \multirow{3}{*}{ Differences of Pathological Grades } & \multicolumn{5}{|c|}{ Significance Level ( $\%$ ) for: } \\
\hline & \multicolumn{4}{|c|}{ Percentage Dried Lung } & \multirow{2}{*}{$\begin{array}{l}\text { Total Estimated } \\
\text { Dust in } \\
\text { Both Lungs (g.) }\end{array}$} \\
\hline & $\begin{array}{l}\text { Total } \\
\text { Dust }\end{array}$ & Coal & $\begin{array}{l}\text { Sil. } \\
\text { Min. }\end{array}$ & Quartz & \\
\hline $\begin{array}{l}2-1 \\
3-1 \\
3-2\end{array}$ & $\begin{array}{l}\text { NS } \\
2 \\
\text { NS }\end{array}$ & $\begin{array}{l}\text { NS } \\
10 \\
\text { NS }\end{array}$ & $\begin{array}{c}\text { NS } \\
1 \\
\text { NS }\end{array}$ & $\begin{array}{l}10 \\
0 \cdot 1 \\
\text { NS }\end{array}$ & $\begin{array}{l}\text { NS } \\
10 \\
\text { NS }\end{array}$ \\
\hline
\end{tabular}

NS $=$ not significant.

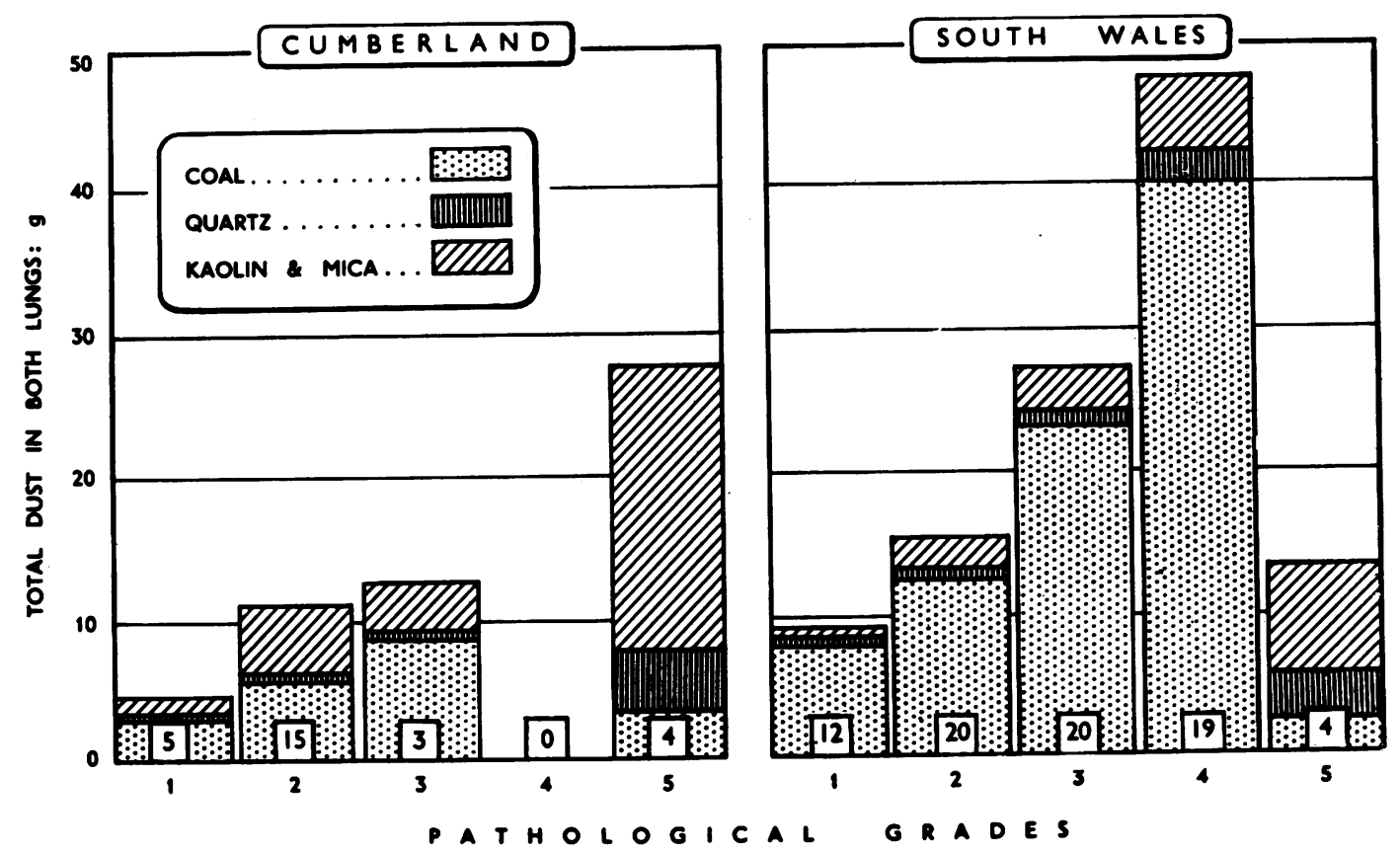

FIG. 6.-Dust content of coal-miners' lungs of different pathological grades. (The numbers in squares show how many cases of each grade were examined.) 
the $1 \%$ level for rock dust, and at the $0.1 \%$ level for quartz. In other words, the more dust there was, and especially the more rock dust and quartz, the more advanced was the fibrosis. The average quartz content of the total lung dust in each grade ranged from $19 \%$ for the silicosis grade to $3.4 \%$ in grade 1 , but only in grade 3 was it significantly higher than in comparable lungs from South Wales, as shown in Table 5. On the other hand, the total dust in

TABLE 5

QUARTZ AS PERCENTAGE TOTAL LUNG DUST IN CUMBERLAND AND SOUTH WALES

\begin{tabular}{|c|c|c|c|c|c|}
\hline $\begin{array}{c}\text { Pathological } \\
\text { Grade }\end{array}$ & 1 & 2 & 3 & 4 & 5 \\
\hline $\begin{array}{l}\text { Cumberland } \\
\text { South Wales* }\end{array}$ & $\begin{array}{l}3.4(6) \\
3.9(11)\end{array}$ & $\begin{array}{l}5 \cdot 8(16) \\
5 \cdot 2(20)\end{array}$ & $\begin{array}{l}7 \cdot 4(5) \\
4 \cdot 6(20)\end{array}$ & $4 \cdot \overline{1(19)}$ & $\begin{array}{l}19(6) \\
23(4)\end{array}$ \\
\hline
\end{tabular}

Figures in brackets are number of lungs in the different groups.

*From King et al. (1956), Table 7, excluding the tin miners and insluding, for grade 5, data from King and Nagelschmidt (1945).

pathological grades 1, 2, and 3 for South Wales was about double that for Cumberland, while the proportion of dusts other than coal was lower (Fig. 6).

\section{Comment}

The composition of dust in the lungs of coal workers with pneumoconiosis in Cumberland shows a broad similarity to that found in the South Wales miners. The same minerals occur, but the amounts of dust are less in the early stages of disease, and the proportion of stone dust is greater and that of coal smaller. Relatively more cases of silicosis are seen at necropsy, and rock dust appears to be comparatively more important in Cumberland than in South Wales in the production of lung pathology. Cases of P.M.F. do not exist or are very rare. The simplest reason for this would be that the men in South Wales were exposed to more respirable dust than those in Cumberland. Mine ventilation in Cumberland was probably better on an average, and the men tended to go to the coalface, where dust concentrations are highest, at a later age than Welsh miners. This effect has been shown to correspond to a shift of about 10 years in the curve relating pneumoconiosis prevalence to dust exposure, when comparing Durham with South Wales coal-miners (McCallum and Browne, 1955). Against this, mechanical cutting advanced earlier in Cumberland (Ministry of Fuel and Power, 1945, Table 1), and increasing mechanization tends to cause higher dust concentrations. It will probably never be possible to know with any degree of accuracy whether between 1920 and 1950, when the bulk of disease with which we are concerned was produced, Cumberland coalmines were less dusty than Welsh anthracite or steam coal-mines.

It is conceivable that there are factors connected with the type of coal which could cause the difference in amount of pneumoconiosis. Coal from Cumberland, which contains much volatile matter, could be less prone to accumulate in the lungs than anthracite and steam coal, which have a lower volatile content, if Cumberland coal is taken up more readily by phagocytes and removed through coughing and swallowing the dust. Animal experiments by injection technique, in which Welsh anthracite and Cumberland coal were compared, failed to give any clear difference in recoveries of these coals from the lungs up to eight to 12 months after injection (Nagelschmidt, Nelson, King, Attygalle, and Yoganathan, 1957), but it could be argued that the injection technique, which introduces massive amounts of dust suddenly into the lungs, is unsuitable to demonstrate this effect. Further research would be required to settle the point. This is in progress, but to date there is no evidence we know of to indicate that one kind of coal dust may be more rapidly eliminated from the lung than another, or against whose access the lung may possess a better barrier. Unless such a difference can be demonstrated between Welsh and Cumberland coal dust, it is probable that the differences in the coal contents of lungs of miners from the two areas are due to lower dust exposures.

Thanks are due to Professor J. Gough for providing the large sections, to Mr. B. A. Maguire for the statistical analyses, and to Misses R. Paul, E. S. Nelson, and J. Vincent for analytical help. One of us (E.J.K.) would like to thank the Medical Research Council and the National Coal Board for financial assistance. This paper is published by permission of the Ministry of Power.

\section{REFERENCES}

Belt, T. H., and King, E. J. (1945). Spec. Rep. Ser. med. Res. Coun. (Lond.), No. 250, p. 29.

Cochrane, A. L., and Miall, W. E. (1956). Brit. med. J., 1, 1193.

Faulds, J. S. (1957). J. clin. Path., 10, 187.

Gordon, R. L., and Harris, G. W. (1956). Safety in Mines Research Establishment, Sheffield, Res. Rep. No. 138.

Gough, J. (1954). Private communication.

King, E. J., and Nagelschmidt, G. (1945). Spec. Rep. Ser. med Res.

Coun. (Lond.), No. 250., p. 1. Med., 13, 9.

McCallum, R. I., and Browne, R. C. (1955). Ibid., 12, 279.

Ministry of Fuel and Power (1945). Coal Mining. Cmd. 6610. H.M.S.O., London.

Nagelschmidt, G., Nelson, E. S., King, E. J., Attygalle, D., and Yoganathan, M. (1957). A.M.A. Arch. industr. Hlth, 16, 188. 